\title{
Analisis Penanganan Manipulasi Transfer Pricing Perpajakan Dalam Menjawab Tantangan Global
}

\author{
Renita Rachma Dewi ${ }^{1}$ \\ Fakultas Ekonomi dan Bisnis \\ Universitas Airlangga, Indonesia \\ Email: dewirenitarachma@gmail.com
}

\author{
Elia Mustikasari² \\ Fakultas Ekonomi dan Bisnis \\ Universitas Airlangga, Indonesia
}

\begin{abstract}
ABSTRAK
Transfer pricing pada dasarnya bertujuan mengukur kinerja perusahaan, dilain sisi juga dapat dijadikan media untuk memanipulasi pajak, sehingga mengakibatkan penerimaan negara yang berakibat pada stabilitas negara, masalah nasional dan tantangan global. Tax ratio Indonesia masih rendah diantara negara Asia Tenggara dan tingkat kepatuhan wajib pajak rendah. Metode penelitian ini adalah kualitatif dengan pendekatan studi kasus transfer pricing. Sumber data adalah sekunder dan proses pengumpulan data dari sumber terpercaya online, sehingga teknik analisisnya menggunakan data reduksi, data display dan verifikasi. Hasil menjelaskan bahwa faktor manipulasi transfer pricing pajak adalah adanya hubungan istimewa perusahaan, sistem dan mekanisme bonus, perolehan laba tak wajar, kepemilikan asing dan political cost. Proses penangannya adalah mereformasi perpajakan, yang mencakup pada SDA, organisasi, proses bisnis, data, teknologi informasi dan regulasi. Peranan behavioral accounting yaitu menciptakan profesionalisme dan tanggungjawab dengan prinsip kewajaran dan kelaziman usaha, value chain analysis, activity based costing dan just in time philosophy.
\end{abstract}

Kata Kunci: Transfer Pricing; Pajak; Behavioral Accounting; Tantangan Global.

\section{Analysis Of Handling Taxation Transfer Pricing In Responding Global Challenges}

\footnotetext{
ABSTRACT

Transfer pricing basically aims to measure company performance and has become a media to manipulate taxes, resulting in state revenue, which results in state stability, national problems and global challenges. This research method is qualitative with the transfer pricing case study approach. The data is secondary and the process of collecting data from reliable online sources. The analysis technique uses data reduction, data display and verification. The results explain that the factors of manipulation of transfer pricing are the presence of special company relationships, bonus systems and mechanisms, acquisition of unnatural profits, foreign ownership and political cost. The process of handling is reforming taxation, which includes natural resources, organizations, business processes, data, information technology and regulation. The role of behavioral accounting is to create professionalism and responsibility with the principles of fairness and custom of business, value chain analysis, activity based costing and just in time philosophy.

Keywords: $\quad$ Transfer Pricing; Tax; Behavioral Accounting; Global Challenges.
}

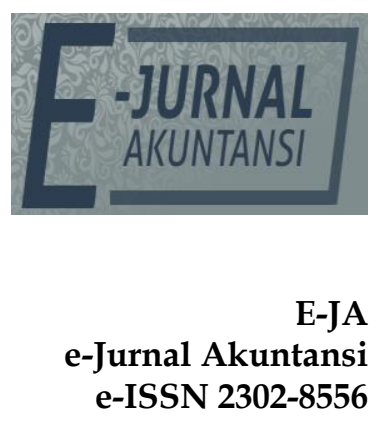

Vol. 30 No. 2

Denpasar, Februari 2020

Hal. 460-473

Artikel Masuk:

9 November 2019

Tanggal Diterima: 4 Februari 2020 


\section{PENDAHULUAN}

Transfer pricing identik dengan adanya manipulasi terhadap angka pajak dalam suatu perusahaan yang sulit dielakkan hingga saat ini. Perusahaan-perusahaan nasional maupun multinasional mempraktikan transfer pricing untuk meminimalkan pajak yang harus dibayarkan kepada pemerintah. Hal ini dilakukan dengan berbagai cara, seperti memanipulasi penetapan harga suatu barang atau jasa terhadap keuntungan yang diperoleh, pemanfaatan celah-celah yang terkandung dalam peraturan-peraturan yang ada, dan adanya kerjasama dengan sumber daya manusia dalam perpajakan sehingga mengabaikan etika perpajakan dan menganggapnya bukan termasuk pelanggaran hukum (Setiawan, 2014).

Transfer pricing dapat dijelaskan sebagai penetapan harga yang bertujuan bagi intra perusahaan yang terjadi pada perusahaan afiliasi, dimana penetapan harga ditentukan dalam transaksi antar pihak yang memiliki hubungan istimewa (Putri, 2017). Transfer pricing juga dapat dijelaskan sebagai transaksi pertukaran produk atau jasa yang terjadi diantara dua perusahaan dalam satu grup perusahaan dengan tujuan tertentu (Huda, Nugraheni, \& Kamarudin, 2017).

Permasalahan klasik transfer pricing perpajakan disebabkan perusahaanperusahaan yang senantiasa berusaha untuk meminimalkan biaya-biaya yang menyangkut perpajakan, bahkan terindikasi hal tersebut sengaja dilakukan sebagai strategi efektif dalam pemenangan persaingan bisnis secara global (Chandra, 2014). Padahal transfer pricing bertujuan untuk mengevaluasi dan mengukur kinerja suatu perusahaan.

Isu sentral dari transfer pricing adalah isu penentuan harga. Pada sisi fiskus dan otoritas pajak memiliki keinginan untuk memastikan bahwa diantara perusahaan yang memiliki hubungan istrimewa maupun tidak akan menggunakan harga wajar dalam setiap transaksi jual beli. Hal ini dikarenakan ketika transaksi dagang tidak menggunakan harga wajar dapat menimbulkan kerugian bagi sebuah negara, yaitu pendapatan dari sektor pajak (Bradley, 2015). Harga wajar sendiri memiliki pengertian sebagai harga atau laba yang terjadi dalam transaksi uyang dilakukan pihak yang tidak memiliki hubungan istimewa yang memenuhi prinsip kelaziman dan kewajaran usaha (Huda et al., 2017). Beberapa indikasi perusahaan melakukan transfer pricing dengan tidak wajar dapat diperhatikan dari harga penjualan, harga pembelian, alokasi biaya administrasi dan umum (overhead cost), pembebanan bunga atas pemberian pinjaman oleh pemegang saham (shareholder loan), pembayaran komisi, lisensi, royalty, dan imbalan atas jasa (Putri, 2017).

Sebagaimana diketahui bahwa terjadi penggerusan pajak dan pengaturan laba yang berdampak pada penguapan 4\%-10\% PPh Badan Global, bahkan merugikan bagi negara berkembang yang mengandalkan pengelolaannya dari pajak mencapai 20\%-30\% (Siregar, 2017). Bahkan menurut Jafri \& Mustikasari (2018), pajak bagi negara berkembang merupakan penerimaan terbesar, yaitu $80 \%$. Artinya, permasalahan manipulasi transfer pricing tidak hanya sebatas penentuan terhadap mekanisme dan sistem perpajakan saja, melainkan perlunya penumbuhan perilaku pajak dan perilaku akuntasi perpajakan yang tumbuh dari kesadaran wajib pajak. 
Maraknya praktik manipulasi transfer pricing telah menggerakan negaranegara maju, maupun berkembang terutama Indonesia untuk mensolusikannya sebaik mungkin, meskipun dalam praktiknya masih belum maksimal sehingga memerlukan standar global mengenai dokumentasi transfer pricing yang mencakup unsur utama penanganannya berupa koherensi, substansi dan transparansi (Siregar, 2017).

Oleh karena itu, pemerintah Indonesia telah mengadopsi berbagai macam model penegakan skema aturan dalam perpajakan mengenai transfer pricing dengan pengontrolan secara teratur melalui 3 dokumen berupa local file, yaitu untuk kewajaran sebuah transaksi; master file, yaitu mengenai deskripsi usaha yang dilakukan; dan country by country report, yaitu penjelasan data keuangan perusahaan dan grupnya (Santoso, 2019).

Menurut Pohan (2019), salah satu penanganan terhadap masalah ini yaitu memberikan otoritas atau wewenang terhadap Menteri Keuangan dan Dirjen Pajak untuk menetapkan penghasilan dan pengurangan serta utang agar dapat menetapkan besaran penghasilan yang dikenai pajak. Hal ini disebabkan keberadaan transfer pricing menciptakan tantangan global pada dampak yang ditimbulkan, penetapan regulasi serta penegakan regulasi tersebut, sehingga terjadi keterbukaan antara pemerintah dan wajib pajak jika terjadi suatu sengketa pajak (Siregar, 2017).

Demikian ini, terjadinya manipulasi transfer pricing pajak tidak lepas dari tingkat kesadaran dan perilaku transfer pricing yang harus dipertimbangkan juga dari segi akuntansi. Adapun perlunya melibatkan akuntansi disebabkan praktik transfer pricing tidak lepas dari perilaku manusia yang terkait dengan sistem akuntasi yang diterapkan dalam perpajakan, dan strategi yang harus dilakukan terkait pajak bagi pemerintah dan perusahaan (Safitri \& Aulia, 2017).

Perilaku manusia yang berkaitan dengan akuntansi dapat dijelaskan dalam behavioral accounting. Behavioral accounting merupakan teori yang memiliki tujuan untuk mengukur dan mengevaluasi setiap faktor keperilakuan yang relevan dan mengomunikasikan informasi mengenai hasil kepada pembuat keputusan internal dan eksternal sehingga dapat melengkapi informasi yang disajikan dalam laporan keuangan (Pendse, 2012).

Berdasarkan hal ini, tujuan dari adanya penelitian adalah mengungkapkan faktor yang menyebabkan manipulasi transfer pricing dalam perpajakan, menjelaskan proses penanganan manipulasi transfer pricing dalam menjawab tantangan global dan menjelaskan peranan behavioral accounting dalam menangani manipulasi transfer pricing.

\section{METODE PENELITIAN}

Penelitian ini menggunakan penelitian kualitatif, yaitu paradigma penelitian yang menekankan pada pemahaman mengenai masalah-masalah dalam kehidupan sosial berdasarkan kondisi realitas atau natural setting yang holistic, komples dan rinci (Arikunto, 2016). Sedangkan pendekatan yang digunakan adalah studi kasus, dalam hal ini yaitu analisis dan pengamatan sebaik mungkin terhadap kasus manipulasi transfer pricing yang terjadi dalam ranah tantangan global dan peranan behavioral accounting agar mendapatkan hasil dan kesimpulan yang objektif. 
Adapun data penelitian yang digunakan adalah sekunder, yaitu data yang tidak didapatkan dari sumber utama, melainkan melalui pengumpulan dan pengkajian data-data dari sumber yang didapatkan sehingga penelitian menjadi pihak kedua untuk mengelola dan mengkritisi data-data yang didapatkan (Moleong, 2017).

Selanjutnya, data-data tersebut dikumpulkan dan didikumentasinya berdasarkan keterkaitannya terhadap kajian penelitian yang didapatkan dari literature-literatur secara online dari internet. Demikian ini, teknik analisisnya menggunakan data reduksi berupa mengumpulkan, merangkum, memilih halhal yang pokok terkait topik penelitian, data display, penyajian data sesuai dengan bentuk-bentuk tertentu yang relevan dengan penelitian dan diuraikan secara singkat hubungan masing-masing kategori, dan verifikasi atau penarikan kesimpulan, baik kesimpulan sementara maupun kesimpulan akhir setelah memperoleh bukti-bukti kuat yang mendukung kesimpulan akhir (Sugiyono, 2012).

\section{HASIL DAN PEMBAHASAN}

Transfer pricing diartikan sebagai harga yang terkait dengan penyerahan barang atau imbalan jasa, sehingga mencakup pada kegiatan-kegiatan usaha yang terkait dengan transaksi, perpajakan, pertanggungjawaban laba atau biaya berdasarkan pada prinsip harga pasar wajar (Aslan, 2018).

Pengertian tersebut mengindikasikan adanya ikatan istimewa antara satu perusahaan dengan perusahaan lainnya, sehingga pengaturan harga rentan terjadi dalam hubungan antar perusahaan tersebut. Hal inilah yang menjadikan adanya tindakan yang inkonstitusional atau amoral bagi para pelaku usaha untuk menghindari hal-hal yang tidak diinginkan, seperti penghindaran pajak.

Hubungan istimewa ini mampu mendorong perusahaan untuk menetapkan harga tak wajar, baik dengan cara menaikan maupun menurunkan dalam rangka memanipulasi pajak melalui transfer pricing. Hal ini dilakukan selain dalam rangka mendapatkan laba sebesar-besarnya, juga menggugurkan wajib pajak sebab merasa memperoleh tekanan dari pemerintah karena menerapkan political cost melalui bayar pajak (Aurinda, 2018). Kedua hal inilah yang menjadi fokus garapan perusahaan-perusahaan dalam meminimalkan pajak sehingga manipulasi transfer pricing menjadi alternatif yang harus dilakukan.

Adanya praktik manipulasi transfer pricing disebabkan faktor-faktor lain yang melekat pada perusahaan. Menurut Yuniasih, Rasmini, \& Wirakusuma (2012) terjadinya transfer pricing disebabkan pemberlakukan pajak oleh pemerintah. Sedangkan Hartati, Winda, \& Azlina (2014) menyebutkan faktor transfer pricing disebabkan sistem dan mekanisme bonus yang telah ditetapkan dalam suatu perusahaan sehingga harus menetapkan manajemen akuntansi yang dominan berpihak pada perusahaan saja.

Oleh karena itu perilaku akuntansi dalam penetapan manajemen perusahaan perlu dilakukan untuk menciptakan keseimbangan dan kesinambungan perusahaan sebagai wajib pajak. Hal ini disebabkan praktik transfer pricing dalam pajak esensinya tidak hanya merugikan perusahaan, melainkan negara dalam menjawab tantangan nasional dan global. Sebab hasil 
pajak dikelola untuk kepentingan negara, sedangkan faktor transfer pricing cenderung adanya faktor memanipulasi jumlah profit agar pajak dan pembagian dividen rendah (Hastutik, 2015).

Hasil penelitian Akbar (2015) terhadap perusahaan manufaktur terdaftar di BEI periode 2010-2014 menunjukkan semakin rendah pajak yang dikeluarkan memungkinkan adanya keputusan transfer pricing. Begitu juga besar kecilnya kepemilikan asing menjadi faktor dalam transfer pricing. Berbeda dengan hasil penelitian Afria (2016) menyatakan bahwa kepemilikan asing tidak mempengaruhi keputusan transfer pricing dalam objek yang sama periode 20112014. Selanjutnya, penelitian Isnaini (2018) terhadap objek yang sama namun dalam periode 2013-2015 menunjukkan tidak hanya pengurangan pajak yang menjadi faktor diterapkannya transfer pricing saja, melainkan tunneling incentive dan exchanga rate juga.

Berdasarkan beberapa faktor keputusan melakukan transfer pricing, pengawasan pemerintah dan kebutuhan informasi sangat perlu diimplementasikan secara optimal, sehingga dapat memberikan manfaat dalam upaya mengelola dan mengembangkan negara untuk menyongsong tantangan global, sebab pajak merupakan salah satu pemasukan negara terbesar.

Pentingnya peranan pemerintah dan instansi pemerintah terkait dalam tingkat pengawasan dan regulasi pajak mempengaruhi terhadap praktik transfer pricing secara positif dan negatif, sebab perusahaan memiliki tujuan tersendiri, sedangkan pemerintah memiliki tujuan umum dalam mengatur sebuah perusahaan agar dapat bermanfaat baginya dan lingkungan secara merata dan adil.

Berkenaan dengan hal tersebut, secara umum Pahlevi, Nuzula, \& Alfandia (2019)menyebutkan faktor pendorong terjadinya transfer pricing adalah adanya arah menuju desentralisasi, divisionalisasi dan penetapan pemberlakuan corporate profit center, penggunaan transfer pricing dalam bisnis dan investasi Internasional berdasarkan kewajiban perusahaan, kebutuhan dan keputusan yang harus ditetapkan untuk keberlangsungan perusahaan atau bisnis, adanya pengawasan transfer pricing oleh aparat perpajakan, bea cukai dan pemerintah, sehingga menuntut wajib pajak melakukan keputusan tertentu, dan kebutuhan dalam pengungkapan segmentasi informasi dan transaksi antar divisi/ unit dan grup dalam perusahaan.

Beberapa faktor tersebut merupakan hal yang umum terjadi dan menyebabkan adanya transfer pricing, bahkan manipulasi transfer pricing dalam rangka menggugurkan wajib pajak terhadap tuntutan pajak yang ditetapkan. Namun dalam perdagangan internasional transfe pricing merujuk pada ketentuan dalam tiper struktur pasar, estimasi terhadap keuntungan maksimal, dan kondisi ekonomi serta regulasi yang ditetapkan dalam suatu negara ( Pahlevi, Nuzula, \& Alfandia, 2019).

Berdasarkan ketentuan ini, timbulnya manipulasi transfer pricing tidak hanya permasalahan dalam perusahaan, melainkan perlu adanya sistem harga dan regulasi pajak yang ditetapkan melalui kebijakan pemerintah dan penegakan hukum yang adil dan merata. Sehingga efek globalisasi dan konglomerasi dapat dikendalikan secara baik agar tujuan transfer pricing dalam penilaian kinerja dan manajemen pajak berjalan semestinya. 
Permasalahan manipulasi dalam transfer pricing tidak hanya mencakup perusahaan domestik, melainkan perusahaan multinasional yang mampu menjadikan anak perusahaan atau grup perusahaannya sebagai transit place untuk memanipulasi harga dan pajak. Permasalahan pajak sebagai masalah yang besar di penjuru dunia dinyatakan oleh sehingga memerlukan akuntan publik yang dapat memeriksa transfer pricing, serta behavioral acoounting sebagai penyeimbang dalam optimalisasi akuntansi publik (Barker, Asare, \& Brickman, 2017).

Salah satu konsep pengaturan dalam harga dan penetapan pajak terdapat dalam kebijakan penetapan harga menggunakan historical cost, bukan standar cost. Adanya standar cost mampu menggerakan suatu perusahaan dalam manajemen akuntansi yang wajar dan tidak wajar untuk menetapkan sebuah harga dan pajak, sehingga perlu diterapkan behavioral accounting untuk mengukur tingkat objetivitasannya, karena rentang terhadap penghembatan biaya dengan alasan efisiensi dan manipulasi harga yang tidak sesuai dalam fakta lapangan (Tampubolon, Karianton, \& Al-Farizi, 2019).

Adapun perlunya penetapan standar harga menggunakan historical cost, meskipun terkesan mengabaikan efisiensi, namun penetapan harga berdasarkan sumber data biaya yang telah ditetapkan dalam perusahaan seiring perjalanan waktu sehingga tidak bersifat kompetitif atas dasar efisiensi.

Regulasi harga untuk mengatur dan menekan terjadinya manipulasi transfer pricing teradapat dalam PER-32/PJ/2011 pasal 4 ayat 2, yaitu "transaksi yang dilakukan antara wajib pajak dengan pihak yang mempunyai hubungan istimewa dianggap sebanding dengan transaksi yang dilakukan antara pihak-pihak yang tidak mempunyai hubungan istimewa dalam hal terdapat perbedaan kondisi, namun dapat dilakukan penyeesuaian untuk menghilangkan pengaruh yang material atau signifikan dari perbedaan kondisi tersebut terhadap harga atau laba."

Penetapan harga yang berimbas pada penegakan pajak secara adil untuk mencegah terjadinya praktik manipulasi transfer pricing dapat dilakukan menggunakan dua penekatan, yaitu: pertama, penetapan perumusan ketentuan domestik. Pemahaman ini menunjukkan bahwa negara dapat mengambil laba global grup berdasarkan pada ketentuan atau formulais tertentu terhadap sumber yang beroperasi sehingga dapat memperoleh bagian dari laba tersebut.

Kedua, negara dapat menentukan laba yang berasal dari cabang usaha atau anak perusahaan yang telah beroperasi di negara di mana perusahaan tersebut berdiri, namun harus dilandasi pada harga yang wajar sebagaimana jika dilakukan kepada pihak-pihak di luar grup perusahaan tersebut (Yoesoef, 2011).

Harga wajar atau laba wajar dan kelaziman usaha dalam penentuan pajak yang harus dikeluarkan oleh wajib pajak dilandasai pada transaksi yang dilakukan oleh pihak-pihak yang tidak memiliki hubungan istimewa dalam suatu perusahaan. Selain itu, persetujuan kepseakatan harga transfer (advance pricing agreement) merupakan salah satu solusi untuk mengentaskan permasalahan manipulasi transfer pricing (Farouq, 2018).

Berdasarkan hasil faktor-faktor terjadinya transfer pricing dapat diketahui mengenai ruang lingkupnya sesuai dengan peraturan Direktur Jenderal Pajak PER-32/PJ.2011 melalui gambar berikut: 


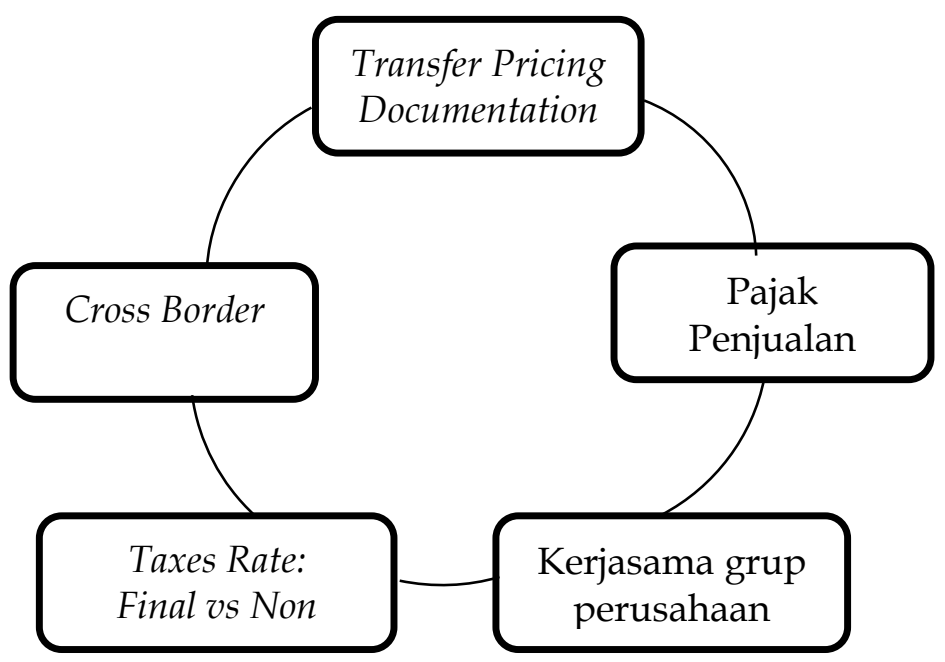

Gambar 1. Ruang Lingkup Transfer Pricing

Sumber: Tampubolon, Karianton, \& Al-Farizi, 2019

Gambar 1. menunjukkan penetapan transfer pricing dilakukan dalam bentuk dokumen yang terkait dengan barang atau hasa dan penetapan harga. Selanjutnya model dokumen disesuaikan dengan jenis perusahaannya, yang biasanya terjadi pada perusahaan multinasional dan melibatkan ketetapan harga antar negara asal sebagai sumber operasional, dan negara lain yang menjadi mitra atau grup perusahaan yang memiliki hubungan istimewa. Hal inilah yang menentukan pajak yang harus dikeluarga berdasarkan kerjasama tersebut dan aturan yang berlaku di suatu negara, sehingga tingkat pajak harus diteliti secara cermat untuk mengetahui terjadi dan tidaknya sebuah manipulasi transfer pricing.

Terjadinya manipulasi transfer pricing tidak hanya berdampak pada suatu perusahaan dan negara tertentu saja, melainkan telah menjadi isu dan tantangan global yang telah terjadi beberapa tahun dan belum menemukan solusi terbaik. Meskipun demikian, beberapa negara telah mempraktikan mekanismemekanisme perpajakan yang disesuaikan dengan perkembangan zaman secara global dan kecanggihan teknologi dan informasi.

Hal ini dapat dilihat dari pertumbuhan ekonomi digital yang menuntut adanya perubahan skema atau model bisnis serta hal-hal terkait dengannya, seperti sistem dan regulasi perpajakan, dan mekanisme penetapan harga agar tidak menimbulkan kecurangan atau manipulasi.

Perlunya pelibatan kemajuan teknologi terhadap perkembangan ekonomi digital dalam menjawab tantangan global sebab adanya manipulasi harga dan pajak disebabkan oleh tiga hal, yaitu: rantai pasokan telah disistemkan menjadi hal yang terintegrasi sehingga mudah dipahami, pertumbuhan ekonomi, terutama menyangkut transfer pricing melibatkan interaksi jarak jauh dengan pelanggan sehingga membutuhkan mekanisme penetapan harga yang wajar, dan peran manusia dapat diganti dengan kecanggihan teknologi melalui perangkatperangkat lunak tertentu (Napitupulu, 2014).

Oleh karena itu, salah satu penanganan yang memungkin untuk mengontrol dan mengurangi terjadi manipulasi transfer pricing adalah penetapan regulasi dalam transfer pricing melalui three-tiered transfer pricing documentation 
(TP Doc) yang mencakup pada master file, local file, dan country by country report (CbCR) (Siregar, 2017).

Dokumen tersebut difungsikan untuk menjawab permasalahan transfer pricing hingga saat ini, yaitu dengan menetapkan tiga prinsip berupa sederhana, murah, dan ketersedian. Ketiga prinsip ini mendorong para wajib pajak untuk melakukan mekanisme dan sistem pajak yang sesuai aturan perundangundangan (Tampubolon et al., 2019).

Maksud prinsip sederhana adalah penyediaan dokumen transfer pricing harus mudah dilakukan dan sederhana, sehingga kebutuhan dalam pengungkapan informasi mudah dilaacar dan memadai. Selanjutnya, prinsip mruah adalah pengurangan terhadap sumber daya atau biaya yang cukup tinggi dalam penentuan transfer pricing untuk pengumpulan informasi yang harus dianalisa secara detail. Kemudian prinsip ketersediaan lebih mengarah kepada kemudahan dalam akses data dan ketepatan waktu melalui beberapa contoh produk sejenis, informasi pasar dan lainnya.

Transparansi dan akuntabilitas transfer pricing melalu mekanisme kemajuan teknologi dan integrasi antar negara ini dapat mengurangi permasalahannya, terlebih di negara berkembang-miskin yang telah disumbang pendapatannya sebesar $80 \%$ dari pajak. Artinya, jika terjadi manipulasi transfer pricing, maka terjadi kerugian besar untuk mengelola suatu negara (Maftuchan, 2013).

Pada sebagian negara, seperti Amerik Serikat telah mengkampanyekan terjadinya penghindaran pajak dengan berbagai cara kepada publik secara massif dan mendunia, yang terkumpul dalam kampange Tax Justice Network (TJN). Hasilnya menunjukkan adanya hubungan kotor antara politisi dengan perusahaan yang mengakibatkan penghindaran pajak. Begitu juga di Inggris, terjadinya manipulasi dalam transfer pricing pajak menggerakkan perdana menteri Inggris, David Cameron menyatakan bahwa hal itu amoral (morally wrong).

Berdasarkan hal ini, peranan pemerintah dan Direktora Jenderal Pajak di Indonesia, sebagaimana di contohkan di negara lain, menjadi sebuah keniscayaan untuk menyongsong dan menguraikan permasalahan transfer pricing pajak. Hal ini menciptakan perhatian serius bagi Menteri Keuangan, Sri Mulyani untuk menggunakan basis data sebagai landasan utama pengumpulan pajak, baik data berasal dari pelaporan wajib pajak, maupun pihak ketiga yang digunakan sebagai komparasi (Kementrian Keuangan Republik Indonesia, 2019). Di sisi lain, dorongan menciptakan kesadaran pajak kepada masyarakat sangat diperlukan untuk mengentaskan permasalahan manipulasi transfer pricing pajak. Sebab fakta lapangan menunjukkan bahwa Indonesia masih mengalami revenue di bawah rata-rata dibandingkan dengan negara lainnya yang mampu mengupulkan pendapatan negaranya dengan baik, seperti Cina 27\% dan Jerman $44 \%$. Dengan demikian, kemampuan negara pun berdampakan pada alokasi dana sektor tertentu dan isu-isu yang diprioritaskan, sehingga mengancam pada tantangan negara terhadap perkembangan global (Kementrian Keuangan Republik Indonesia, 2019).

Penanganan masalah manipulasi transfer pricing pajak dan perpajakan secara umum di Indonesia, masih membutuhkan kerja keras pemerintah dan 
masyarakat dalam mematuhi dan menyadari wajib pajak. Di antara program yang dijadikan untuk menyadarkan wajib pajak masyarakat, termasuk agar tidak terjadi manipulasi transfer pricing adalah program tax amnesty yang telah dijalankan tahun 2016-2017 dan mengalami penginkatan sebesar 70,98 persen yang sebelumnya sebesar 61 persen (Kementrian Keuangan Republik Indonesia, 2019).

Selain itu, upaya pemerintah dalam menangani masalah transfer pricing dan perpajakan melalui reformasi perpajakan yang mencakup pada keorganisasiannya, sumber daya manusia, proses bisnis, data, teknologi informasi dan regulasi. Perlunya reformasi ini disebabkan Indonesia mengalami tax ratio rendah dibandingkan negara Asia Tenggara lainnya, seperti, Thailand 16,5\%, Malaysia 14,4\%, Filipina 13,67, Singapura 14, 29 dan Kamboja, 15,35. Sedangkan Indonesia masih 11,5\% tahun 2018 (Kementrian Keuangan Republik Indonesia, 2019).

Keseriusan pemerintah sebagai regulator dalam menangani permasalahan manipulasi pajak dengan berbagai bentuknya, seperti transfer pricing diwujudkan dengan diresmikannya dua Direktorat dalam naungan Direktora Pajak, berupa Direktorat Data Informasi Perpajakan dan Direktorat Teknologi Informasi dan Komunikasi (Sembiring, 2019). Namun menurut pendapat Reza sebagai penelitian Pajak Institute for Development of Economics and Finance (INDEF) mengatakan pembentukan kedua direktorat tersebut tidak dapat berjalan secara efektif, sebab sebenarnya ada hal yang lebih penting dari itu berupa pemisahan wewenang, meskipun dukungan pembentukan keduanya juga datang sebagai penyambutan tahun 2020 dan komitmen dalam model perpajakan (Thomas, 2019).

Setidaknya dalam penanganan transfer pricing untuk meminimalisir manipulasi pajak dan meningkatkan tax ratio negara dilakukan melalui beberapa langkah dalam dokumen transfer pricing, agar terjadi transparansi dan memudahkan analisa bagi pemerintah terkait, sebagai berikut:

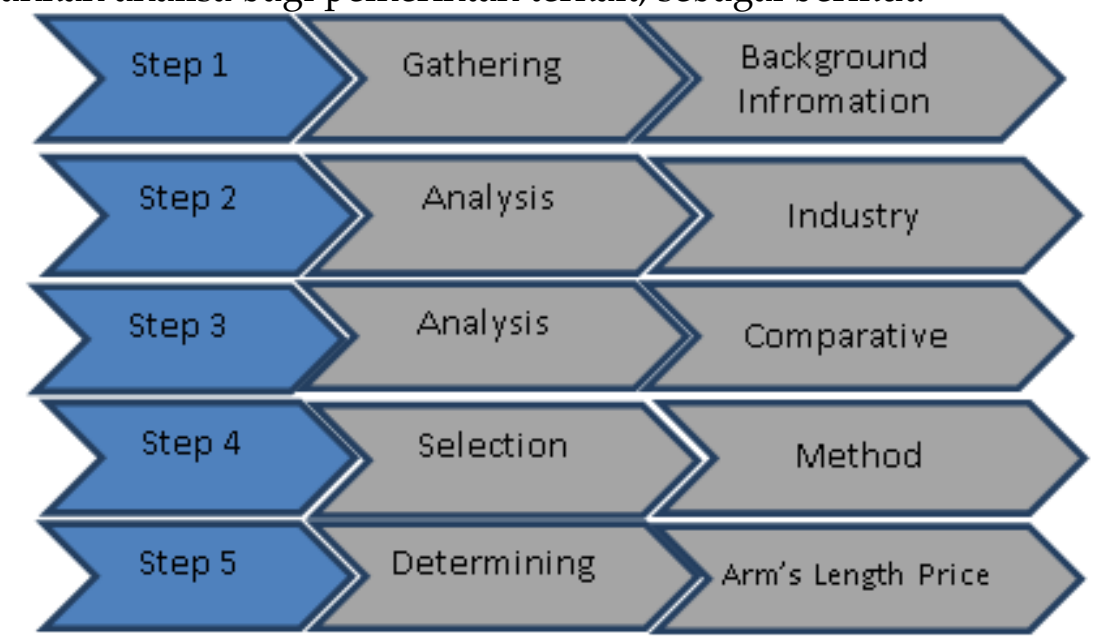

Gambar 2. Studi Transfer Pricing

Sumber: Tampubolon, Karianton, \& Al-Farizi, 2019 
Gambar 2. menunjukkan proses transfer pricing sebenarnya dapat dianalisa dengan sebaik mungkin untuk mencegah terjadinya manipulasi pajak. Hal ini diperlihatkan dengan tahapan-tahapan di atas, yaitu pengumpulan informasi latar belakang, analisis industri, analisis perbandingan, penentuan metode yang tepat dalam penetapan harga dengan landasan prinsip wajar dan lazim usaha, dan penentuan harga pertukaran.

Demikian ini juga, Indonesia untuk menjawab permasalahan dalam negeri dan tantangan global telah, selain penanganan yang telah disebutkan, juga melakukan penanganan lainnya, seperti penerbitan regulasi yang khusus menangani transfer pricing yang tercermin dalam UU No. 7/1983 tentang Pajak Penghasilan (PPh), UU No. 36/2008 tenteang Perubahan Keempat UU sebelumnya, UU No. 8/1983 tentang Pajak Pertambahan Nilai Barang dan Jasa dan pajakan Penjualan Atas Barang Mewah (PPn), Peraturan Dirjen Pajak No PER-43/PJ/2010 direvisi menjadi No PER-32/PJ/2011, Peraturan Dirjen Pajak No PER-61/PJ/2010 tentang tata cara penerapan penghindaran Pajak Berdanda dan lainnya, adanya persetujuan penghindaran pajak berganda dan pencegahan pengelakan pajak dengan negara lain, dan penandatanganan konvensi OECD tentang timbal balik administratif perpajakan (Maftuchan, 2013).

Tidak hanya ketiga langkah di atas saja, dalam tataran strategis, khususnya untuk menangani manipulasi transfer pricing dan penghindaran pajak, serta optimalisasi penerimaan negara dan reformasi administrasi perpajakan, pada tahun 2015-2019 ditetapkan beberapa sasaran strategis agar mampu menjawab permasalahan nasional dan global, yaitu: penerimaan pajak secara optimal, pemenuhan layanan publik, kepatuhan wajib pajak yang tinggi, pelayanan prima, peningkatan efektivitas penyuluhan dan kehumasan, peningkatan ekstensifikasi perpajakan, peningkatan, pengawasan wajib pajak, peningkatan efektvitias pemeriksaan, peningkatan efektivitas penegakan hukum, penignkatan kehandalan data, dan organisasi dan transformasi yang handal (Direktorat Jenderal Pajak, 2018).

Adanya praktik manipulasi transfer pricing disebabkan etika dan i'tikad yang rendah bagi wajib pajak, sehingga fungsi transfer pricing sebagai pengendali kinerja perusahaan tidak dapat berfungsi secara optimal, malahan menjadi media untuk melegalkan penghindaran dan manipulasi pajak perusahaan.

Padahal pada prinsip kewajaran dan kelaziman usaha merupakan salah satu celah yang menunjukkan harus diaplikasikannya akutnansi keperilakuan. Prinsip ini tidak mendistorsikan dan mendiskriminasikan pihak-pihak tertentu, melainkan lebih pada pemerataan terhadap mekanisme dan tata aturan yang berlaku dalam transfer pricing.

Keadaan dalam memproses transfer pricing agar tidak terjadi manipulasi dibutuhkan perilaku akuntansi yang menunjukan pada tingkat kompetensi, profesionalisme dan komitmen terhadap apa yang telah menjadi tugas dan kewajibannya (Pratiwi \& Widhiyani, 2017). Artinya segala sesuatu yang diperhitungkan terkait dengan akuntansi perusahaan harus mencerminkan ketiga hal tersebut, sehingga tidak merugikan pihak manapun, apalagi suatu negara.

Demikian ini, perilaku akuntansi menuntut kepada para wajib pajak untuk mewujudkan sikap profesionalismenya dalam menerapkan aturan dan 
mentaatinya sebagaimana yang telah berlaku. Oleh karena itu, adanya akuntasi perilaku yang menjadi bagian dari akuntansi manajemen dalam menangani permasalahan manipulasi transfer pricing sangat diperlukan.

Setidaknya terdapat tiga konsep yang dapat diperankan oleh akuntansi perilaku sebagai manajemen dalam transfer pricing, yaitu value chain analysis, activity based costing $(A B C)$, dan just in time philospihy. Adapun tujuan konsep pertama adalah untuk penyusunan rencana strategis dan berkarakter pada tekanan tehradap identifikasi sumber-sumber pajak, hubungan antar aktivitas usaha terkait dengan pajak, dan identifikasi unsur-unsur biaya strategi terkait dengan pembentukan nilai aktivitas yang diinginkan.

Sedangan value chain merupakan penelaahan terhadap beberapa aktivitas perusahaan terkait dengan penetapan harga, pajak dan hal-hal terkait dengan keduanya. Kemudian, ABC merupakan bagaimana infromasi kinerja finansial dan operasional terkadi transfer pricing dapat diperoleh secara akurat dan dapat dipertanggungjawabkan sehingga mampu menciptakan wajib pajak yang taat. Sedangkan just in time (JIT) merupakan falsafah yang difungsikan untuk memperhatikan perubahan yang terjadi dilingkungan, seperti adanya praktik manipulasi transfer pricing yang harus disolusikan secara bertahap dengan berbagai usaha (Rahman, 2018).

\section{SIMPULAN}

Berdasarkan hasil penelitian permasalahan manipulasi transfer pricing perpajakan tidak hanya menyebabkan permasalahan nasional sebab penerimaan negara yang masih rendah dan kesadaran masyarakat wajib pajak rendah, namun dapat menjadi tantangan global sebab tax ratio negara masih lebih rendah daripada negara-negara Asia Tenggara lainnya sehingga pengelolaan pembangunan dan pertumbuhan negara tidak berjalan optimal.

Adapun faktor terjadinya manipulasi transfer pricing pajak disebabkan hubungan istimewa antar grup perusahaan, berlakunya sistem dan mekanisme bonus yang diterapkan dalam perusahaan, keinginan perusahaan untuk mendapatkan laba semaksimal mungkin sehingga menekan pajak seminimal mungkin, kepemilikan asing dan terjadinya political cost yang melibatkan suatu perusahaan di suatu negara.

Oleh karena itu, manipulasi transfer pricing perpajakan dapat ditangani dengan melakukan reformasi perpajakan oleh pemerintah dan melakukan langkah-langkah strategis dalam pengelolaan dan pengumpulan pajak. Demikian ini juga, diperlukan peranan behavioral accounting dalam perpajakan melalui penerapan profesionalisme dan tanggungjawab yang dilandasri pada prinsip kewajaran dan kelaziman usaha, value chain analysis, activity based costing dan just in time philosophy.

\section{REFERENSI}

Afria, Y. (2016). Analisis Faktor-Faktor Yang Mempengaruhi Keputusan Transfering Pricing Perusahaan Manufaktur di Bursa Efek Indonesia (BEI) 2011-2014. Unversitas Setia Budi. 
Akbar, R. . (2015). Analisis Faktor-Faktor yang Mempengaruhi Keputusan Transfer Pricing Pada Perusahaan Manufaktur di Bursa Efek Indonesia. Universitas Katolik Widya Mandala.

Arikunto, S. (2016). Prosedur Penelitian Suatu Pendekatan Praktik. Jakarta: Rineka Cipta.

Aslan. (2018). Peluang dan Tantangan Negara-Negara di Kawasan Borneio Dalam Menghadapi Mea (Proceeding of 1st International Conference on ASEAN Economic Community in Borneio Region). Sambas: Ebooksia.

Aurinda, N. U. (2018). Analisis Faktor-faktor Yang Mempengaruhi Keputusan Perusahaan Untuk Melakukan Transfer Pricing. Universitas Lampung.

Barker, J., Asare, K., \& Brickman, S. (2017). Transfer pricing as a vehicle in corporate tax avoidance. Journal of Applied Business Research, 33(1), 9-16.

Bradley, W. (2015). Transfer Pricing: Increasing Tension Between Multinational Firms And Tax Authorities. Accounting \& Taxation, 7(2), 65-73. Retrieved from

http:/ / search.proquest.com/docview/1727471238?accountid=11440

Chandra, T. M. (2014). Pengaruh Transfer Pricing Terhadap Perencanaan Pajak Bagi Perusahaan Multinasional. Jurnal Akuntansi Unesa, 2(2).

Direktorat Jenderal Pajak. (2018). Laporan Kinerja Direktorat Jenderal Pajak. Jakarta.

Farouq, M. (2018). Hukum Pajak di Indonesia: Suatu Pengantar Ilmu Hukum Terapan di Bidang Perpajakan. Jakarta: Kencana.

Hartati, Winda, D., \& Azlina, N. (2014). Analisis Pengaruh Pajak dan Mekanisme Bonus Terhadap Keputusan Transfer Pricing: Studi Empiris Pada Seluruh Perusahaan Yang Listing di Bursa Efek Indonesia. Jurnal Simposium Nasional Akuntansi 17.

Hastutik, R. D. (2015). Faktor Transfer Pricing dan Problematikan Praktik Penghindaran Pajak (tax Avoidance). Universitas Muhammadiyah.

Huda, M. K., Nugraheni, N., \& Kamarudin, K. (2017). The Problem of Transfer Pricing in Indonesia Taxation System. International Journal of Economics and Financial Issues, 7(4), 139-143.

Isnaini, N. (2018). Analisis Faktor-Faktor Yang Mempengaruhi Keputusan Transfer Pricing Perusahaan Manufaktur Yang Terdaftar di Bursa Efek Indonesia Tahun 2013-2015. Universitas Muhammadiyah Gresik.

Jafri, H. E., \& Mustikasari, E. (2018). Pengaruh Perencanaan Pajak, Tunneling Incentive dan Aset Tidak Berwujud Terhadap Perilaku Transfer Pricing Pada Perusahaan Manufaktur Yang Memiliki Hubungan Istimewa Yang Terdaftar di Bursa Efek Indoneesia Periode 2014-2016. Berkala Akuntansi Dan Keuangan Indonesia, 3(2).

Kementrian Keuangan Republik Indonesia. (2019). Menkeu Tekankan Pentingnya Peran Data Untuk Pengumpulan Pajak. Retrieved November 8, 2019, from Kemenkeu.go.id website: https://www.kemenkeu.go.id/publikasi/berita/menkeu-tekankanpentingnya-peran-data-untuk-pengumpulan-pajak/

Maftuchan, A. (2013). G-20 dan Transparansi Perpajakan Global Memperkuat Peran Indonesia Dalam Penindakan Praktik Transfer Pricing. International NGO Forum on Indonesian Development (INDIF) Dan Oxfam. 
Moleong, L. J. (2017). Metode Penelitian Kualitatif (30th ed.). Jakarta: Remaja Rosdakarya.

Napitupulu, B. (2014). Pengaruh Penerapan Sistem Administrasi Perpajakan Modern Berbasis Teknologi Informasi Terhadap Kepatuhan Wajib Pajak Pada KPP Madya Medan. Jurnal Administrasi Publik, 2(1), 40-55.

Pahlevi, K. A., Nuzula, N. F., \& Alfandia, N. S. (2019). Pemanfaatan Transfer Pricing Documentation Pada Pemeriksaan Transfer Pricing Untuk Menilai Kewajaran Dan Kelaziman Transaksi Afiliasi (Studi pada Kantor Pelayanan Pajak Penanaman Modal Asing Empat). Jurnal Administrasi Bisnis, 73(1), 69-77.

Pendse, S. J. (2012). International Transfer Pricing: A Review of Non-Tax Outlook. Procedia - Social and Behavioral Sciences, 37, 337-343.

Pohan, C. A. (2019). Pedoman Lengkap Pajak Internasional Konsep, Strategi, dan Penerapan. Jakarta: Gramedia Pustaka Utama.

Pratiwi, V. T., \& Widhiyani, N. L. S. (2017). Pengaruh Profesionalisme, Komitmen Organisasi, Etika Profesi, dan Pengalaman Auditor Pada Tingkat Pertimbangan Materialitas. E-Jurnal Akuntansi Universitas Udayana, 19(2), 1463-1489.

Putri, W. A. (2017). Prinsip Kewajaran dan Dokumen sebagai Penangkal Kecurangan Transfer Pricing di Indonesia. Jurnal Riset Akuntansi Dan Keuangan, 2(2), 47-56. https:// doi.org/10.17509/jrak.v5i2.8029

Rahman, Z. (2018). Analisis Perlakuan Akuntansi Konstruksi Pengerjaan Dalam Penyajian Laporan Keuangan pada Dinas Pekerjaan Umum Kota Gorontalo. Gorontalo Accounting Journal, 1(1), 59. https://doi.org/10.32662/gaj.v1i1.80

Safitri, R. H., \& Aulia, B. (2017). Optimalisasi Peran Behavioral Accounting Guna Penerapan Dalam Praktik Transfer Pricing. Seminar Nasional Akuntansi Dan Bisnis, 1038-1044.

Santoso, Y. I. (2019). Perlu Ada Kontrol Dari Pemerintah Untuk Menghindari Transfer Pricing. Retrieved November 22, 2019, from Kontan.co.id website: https://nasional.kontan.co.id/news/perlu-ada-kontrol-daripemerintah-untuk-menghindari-transfer-pricing

Setiawan, H. (2014). Transfer Pricing dan Risikonya Terhadap Penerimaan Negara. Jakarta.

Siregar, B. (2017). Memahami Isu Transfer Pricing. Retrieved November 22, 2019, from DDTC news website: https://news.ddtc.co.id/memahami-isutransfer-pricing-9229?page_y $=900$

Sugiyono. (2012). Metode Penelitian Kuantitatif, Kualitatif dan $R \mathcal{E}$ D. Bandung: Alfabeta.

Tampubolon, Karianton, \& Al-Farizi, Z. (2019). Transfer Pricing dan Cara Membuat TP DOC. Yogyakarta: Deepublish.

Thomas, V. F. (2019). Kemenkeu \& DJP Diminta Pisah daripada Bentuk Dua Direktorat Baru. Retrieved November 22, 2019, from Tirto.id website: https://tirto.id/kemenkeu-djp-diminta-pisah-daripada-bentuk-duadirektorat-baru-edYk

Yoesoef, A. J. (2011). Fungsikan surveyor: jangan biarkan asing kuras tambang kita. Jakarta: PT Elex Media Komputindo. 
Yuniasih, N. W., Rasmini, N. K., \& Wirakusuma, M. G. (2012). Pengaruh Pajak dan Tunneling Incentive Pada Keputusan Transfer Pricing Perusahaan Manufaktur Yang Listing di Bursa Efek Indonesia. Jurnal Universitas Udayana. 